\title{
Pseudo-fractionation trend of the Fiskenæsset anorthosite complex, southern West Greenland
}

\author{
John S. Myers
}

The Fiskenæsset anorthosite complex is a sheet of layered igneous cumulates, 350$400 \mathrm{~m}$ thick, which was intruded into volcanic rocks, now amphibolites (Escher \& Myers, this report). It was later disrupted by the intrusion of an enormous amount of granitoid material, mainly as sheets during regional deformation, and was metamorphosed in amphibolite and hornblende granulite facies about $2850 \mathrm{~m}$.y. ago (Black et al., 1973). Fragments of similar rocks are widespread throughout the Archaean gneiss complex of Greenland, although the name Fiskenæsset complex is limited to the occurrences in the Fiskenæsset region (Bridgwater et al., in press).

\section{Previous work}

The first attempts to understand the fractionation pattern of the intrusion were made by Bowden (1970) and Gormsen (1971), and these results are described at length by Herd (1972), Windley (1973) and Windley et al. (1973) (fig. 15). Windley et al. (1973, p. 2) concluded that the intrusion was "the differentiation product of a basaltic magma" and (op. cit., p. 73) "formed from a hydrous melt similar to the calc-alkali extrusive rocks series", with a decrease in total iron with differentiation. They considered that the marked upward increase in $\mathrm{Fe} / \mathrm{Mg}$ ratio best defined the course of crystallisation of the intrusion.

\section{New work}

The major element content of whole rock powders of numerous samples from the Majorqap qâva outcrop of the anorthosite complex was recently determined. This outcrop is less deformed and preserves more of its igneous mineralogy than the rocks studied by Windley et al. (1973). Most rocks are composed of plagioclase and hornblende with a small amount of mica. The major igneous stratigraphy of the Majorqap

Table 2. Igneous stratigraphy of the Majorqap qâva outcrop, with the average proportions of the main minerals and average thicknesses of the main rock units

\begin{tabular}{llcc}
\hline & Rock unit & Plagioclase & Hornblende \\
\hline Top & Anorthosite $200 \mathrm{~m}$ & 95 & 5 \\
& Upper Leucogabbro $60 \mathrm{~m}$ & 80 & 20 \\
& Gabbro $40 \mathrm{~m}$ & 50 & 50 \\
Bottom & Lower Leucogabbro $50 \mathrm{~m}$ & 80 & 20 \\
\hline
\end{tabular}




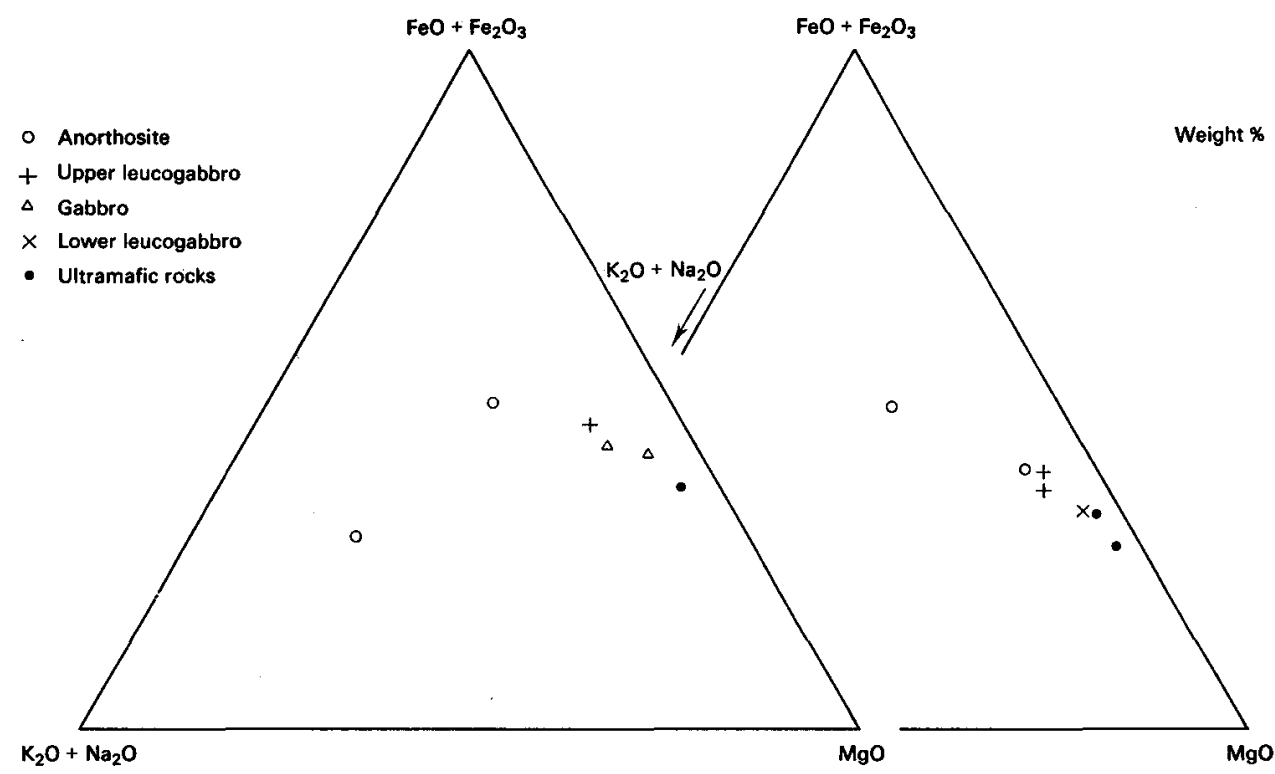

Fig. 15. AFM diagrams of whole rock analyses from two sections of the anorthosite complex on Qeqertarssuatsiaq showing rocks collected in ascending stratigraphic order, from ultramafic rocks to anorthosite (after Windley et al., 1973, modified to show the same stratigraphic divisions as in fig. 16). The patterns were interpreted as the differentiation trends of the complex.

qâva outcrop is summarised in Table 2. In addition ultramafic layers, 1-2 $\mathrm{m}$ thick, also occur in the lower three units.

The distribution of 70 rocks from this succession are shown plotted on an AFM diagram in fig. 16. The distribution resembles a fractionation pattern, but this resemblance is more apparent than real. The points fall into groups related to rock type rather than to stratigraphic position. The leucogabbros from both the upper and lower leucogabbro units cluster together, and ultramafic rocks from the lower leucogabbro, gabbro and upper leucogabbro units form another cluster of points independent of their stratigraphic positions. Comparison of the many analyses of fig. 16 with the reconnaissance work by Windley et al. (1973) suggests that their differentation trend (fig. 15) may not be representative.

\section{Discussion}

An AFM diagram reflects about $21 \%$ of the composition of a tholeiitic basalt, but only $4 \%, 10 \%$ and $18 \%$ respectively of the composition of the anorthosite, leucogabbro and gabbro of the Fiskenæsset complex. These rock types, rich in calcium and aluminium, and poor in iron and alkalis, are therefore represented less adequately than tholeiitic basalt in an AFM diagram. Small differences in the relative amounts of plagioclase, hornblende and mica in the anorthosite samples are exaggerated on the AFM diagram. This is illustrated in fig. 16a which shows the distribution of 9 


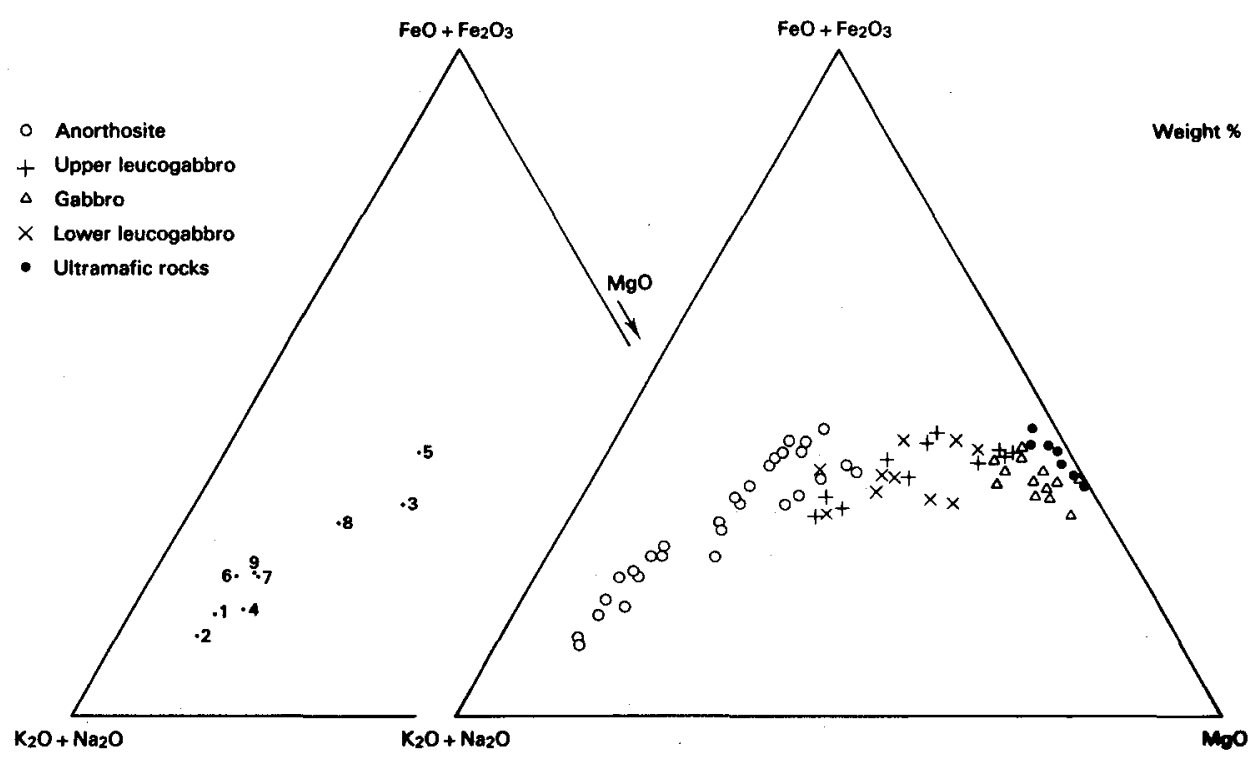

Fig. 16. AFM diagrams of whole rock analyses from the anorthosite complex at Majorqap qâva. $a$ (left): samples collected at $25 \mathrm{~m}$ intervals in ascending stratigraphic order 1 to 9 from the anorthosite unit. $b$. (right): 70 samples from three sections across the main stratigraphic units showing a pseudo-fractionation trend.

samples of anorthosite collected at $25 \mathrm{~m}$ intervals through the anorthosite unit. The position of the samples on the AFM diagram bears no systematic relation to their stratigraphic position but may reflect small variations in the relative proportions of minerals in the rock samples.

The apparent fractionation trend shown on fig. $16 \mathrm{~b}$ is similar to that obtained by Hutt (1974) from other sections of the Fiskenæsset anorthosite complex. Hutt suggested that the trend represents differentiation with less marked iron enrichment than that shown on fig. 15, and that the two trends may indicate two anorthosite intrusions with slightly different bulk compositions. It is suggested here that this difference is more apparent than real because of the inadequacy of the AFM diagram to represent these calcium-aluminium rich cumulates.

\section{Conclusions}

The distribution of points on fig. $16 \mathrm{~b}$ shows that there are small but significant variations in $\mathrm{Fe} / \mathrm{Mg}$ ratio between gabbro, leucogabbro and anorthosite samples. However, the broad spread of points representing leucogabbro and anorthosite samples mainly reflects variations in the proportions of plagioclase, hornblende and mica in the rocks. There is only a slight increase in the $\mathrm{Fe} / \mathrm{Mg}$ ratio of anorthosite relative to leucogabbro. If this difference is the result of igneous fractionation, the amount of fractionation between the anorthosite at the top of the intrusion and the leucogabbro at the bottom is small. There is a greater difference between the $\mathrm{Fe} / \mathrm{Mg}$ ratio 
of the gabbro samples relative to all the leucogabbro samples together than between samples from the upper and lower leucogabbro units, above and below the gabbro unit. Relative to the gabbro samples, the ultramafic rocks have similar, rather than lower, $\mathrm{Fe} / \mathrm{Mg}$ ratios, probably because of the greater content of magnetite in the ultramafic rocks.

Many of the amphibolites into which the anorthosite complex was intruded appear to be derived from volcanic rocks with oceanic tholeiite composition (C. R. L. Friend, personal communication). This suggests that the composition of the earth's mantle was already similar to that at the present time before the intrusion of the anorthosite complex. If the anorthosite complex was derived by fractionation from magma of oceanic tholeiite composition, a mafic-rich fraction must have separated from the magma before it was intruded into its present host rocks, and any alkali-rich fraction which may have formed must also have been lost. Thus, the sill-like Fiskenæsset anorthosite complex may represent only a small part of the probable fractionation process by which it may have been derived from a tholeiitic magma.

\section{References}

Black, L. P., Moorbath, S., Pankhurst, R. J. \& Windley, B. F. 1973: ${ }^{207} \mathrm{~Pb} /{ }^{206} \mathrm{~Pb}$ whole rock age of the Archaean granulite facies metamorphic event in West Greenland. Nature, Lond. 244, 50-53.

Bowden, A. A. 1970: The geochemistry of a traverse across the Fiskenæsset anorthosite complex, West Greenland. Unpublished MSc thesis, Univ. of Leeds, 64 pp.

Bridgwater, D., Keto, L., McGregor, V. R. \& Myers, J. S. in press: The Archaean gneiss complex of Greenland. In Escher, A. \& Watt, W. S. (edit.) Geology of Greenland. Copenhagen: Geol. Surv. Greenland.

Gormsen, K. 1971: En geologisk unders $\emptyset$ gelse af det chromitførende Fiskenæsset kompleks omkring Taseq, Vestgrønland. Unpublished thesis, Univ. of Copenhagen. 99 pp.

Herd, R. K. 1972: The petrology of the sapphirine-bearing and associated rocks of the Fiskenæsset complex, West Greenland. Unpublished Ph.D. thesis, Univ. of London. 606 pp.

Hutt, D. K. 1974: The geology and geochemistry of part of the Fiskenæsset anorthosite complex, West Greenland. Unpublished Ph.D. thesis, Univ. of London. 316 pp.

Windley, B. F. 1973: The chemistry of the Fiskenæsset complex on Qeqertarssuatsiaq. Rapp. Grфnlands geol. Unders. 51, 41-46.

Windley, B. F., Herd, R. K. \& Bowden, A. A. 1973: The Fiskenæsset complex, West Greenland. Part I: A preliminary study of the stratigraphy, petrology, and whole rock chemistry from Qeqertarssuatsiaq. Bull. Grønlands geol. Unders. 106 (also Meddr Grønland 196,2) 80 pp. 